\title{
Korelasi Penanda Anatomis Blokade Saraf Iskiadikus Pendekatan Anterior dengan Panjang Femur dan Tinggi Badan Menggunakan Ultrasonografi
}

\author{
Maransdyka Purnamasidi, ${ }^{1}$ Erwin Pradian, ${ }^{2}$ Rudi Kurniadi K. ${ }^{2}$ \\ ${ }^{1}$ Rumah Sakit Mitra Kemayoran Jakarta, ${ }^{2}$ Departemen Anestesiologi dan Terapi Intensif Fakultas \\ Kedokteran Universitas Padjadjaran Rumah Sakit Dr. Hasan Sadikin Bandung
}

\begin{abstract}
Abstrak
Blokade saraf iskiadikus pendekatan anterior dapat digunakan untuk memfasilitasi pembedahan di bawah lutut dan sangat bermanfaat untuk pasien yang tidak dapat diposisikan lateral. Tujuan penelitian ini untuk mencari korelasi penanda anatomis blokade saraf iskiadikus pendekatan anterior dengan panjang femur dan tinggi badan menggunakan ultrasonografi pada subjek penelitian laki-laki. Metode penelitian ini adalah observasional eksperimental dengan pengambilan data secara cross sectional di ruang operasi bedah sentral Rumah Sakit Dr. Hasan Sadikin Bandung pada September-November 2012. Persamaan korelasi panjang femur dan tinggi badan dengan penanda anatomis blokade saraf iskiadikus pendekatan anterior dihitung berdasarkan analisis regresi linear dan uji analysis of variance (ANOVA) untuk menentukan kelayakan persamaan regresi linear, pada taraf kepercayaan 95\%. Hasil penelitian menunjukkan korelasi yang kuat antara penanda anatomis blokade saraf iskiadikus pendekatan anterior dan panjang femur $(r=0,784)$ dengan korelasi searah dan bermakna $(p<0,05)$. Terdapat korelasi yang sangat kuat antara penanda anatomis blokade saraf iskiadikus pendekatan anterior dan tinggi badan $(\mathrm{r}=0,921)$ dengan korelasi searah dan bermakna $(\mathrm{p}<0,05)$. Berdasarkan hasil analisis regresi linear, diperoleh persamaan: Titik " $\mathrm{P}$ " $=(0,182 \mathrm{x}$ tinggi badan) $-24,647 \mathrm{~cm}$. Titik "P" (0,275 x panjang femur)-4,764 cm. Simpulan, penelitian ini menunjukkan bahwa terdapat korelasi penanda anatomis blokade saraf iskiadikus pendekatan anterior dengan panjang femur dan tinggi badan menggunakan ultrasonografi.
\end{abstract}

Kata kunci: Blokade saraf iskiadikus, pendekatan anterior, panjang femur, tinggi badan, ultrasonografi

\section{Anterior Approach to the Sciatic Nerve Block in Correlation with Femur Length and Patient's Height Using Ultrasound As a Guidance}

\begin{abstract}
Anterior sciatic nerve blocks is an alternative anesthetic technique for below knee surgery and very useful for patients that cannot positioned laterally. This study was conducted to improve correlations between anterior sciatic anatomical marking with femur length and patient's height using ultrasound as a guidance. The method of this study was a cross sectional experimental observation study in central operating theatre Dr. Hasan Sadikin Hospital-Bandung within September-November 2012. Correlation formula between femur length or patient's height and anterior sciatic anatomical marking was calculated using linear regression analytic and analysis of variance (ANOVA) test with interval of confidence 95\%. A total of 92 subject, between 25 to 47 years studied. The results of this study showed a strong correlation between anterior sciatic anatomical marking and femur length $(\mathrm{r}=0.784) \mathrm{p}<0.05$, a very strong correlation between anterior sciatic anatomical marking and subject's height $(\mathrm{r}=0.921)$ and $\mathrm{p}<0.05)$. Formula based on linear regression analysis: "P" point $(0.275 \mathrm{x}$ femur length $)-4,764 \mathrm{~cm}$. "P" point $=(0.182 \mathrm{x}$ height $)-24,647 \mathrm{~cm}$. The conclusion of this study shows correlation between anterior sciatic anatomical marking with femur length and patient's height using ultrasound.
\end{abstract}

Key words: Anterior approach, femur length, height, sciatic block, ultrasound

Korespondensi: Maransdyka Purnamasidi, dr., SpAn, RS. Mitra Kemayoran, Jl. HBR Motik (Landas Pacu Timur), Kemayoran-Jakarta 10630, mobile 081315767191, email maransdyka@ymail.com 


\section{Pendahuluan}

Penggunaan blokade saraf iskiadikus sering dikombinasikan dengan blokade pada pleksus lumbalis untuk prosedur operasi ekstremitas bawah sebagai pilihan anestesi alternatif dari anestesi umum dan juga blokade neuroaksial. ${ }^{1-5}$ Teknik blokade saraf iskiadikus merupakan teknik blokade ekstremitas bagian bawah yang jarang digunakan ${ }^{2,6-8}$ Alasan blokade ini jarang dilakukan karena keterampilan yang kurang dan kesulitan saat melakukan teknik blokade saraf iskiadikus. ${ }^{2,5,9}$

Pendekatan yang dilakukan saat melakukan blokade saraf iskiadikus, yaitu dalam posisi terlentang dan posisi sims. Saraf iskiadikus dapat diakses melalui pendekatan posterior, ${ }^{10}$ anterior, atau lateral. ${ }^{1,2,5}$ Teknik blokade saraf iskiadikus melalui pendekatan posterior ini pertama kali dilakukan oleh Labat $^{10}$ tahun 1930 yang diperbaiki dengan teknik Winnie. ${ }^{11}$ Tahun 1959, Ichiyanahi ${ }^{12}$ mempublikasikan pendekatan lateral pada teknik blokade saraf iskiadikus. Teknik dengan pendekatan lateral ini banyak dilakukan pada pasien anak. ${ }^{13}$

Blokade saraf iskiadikus dapat dilakukan menggunakan pendekatan dari arah anterior; pendekatan ini akan sangat bermanfaat pada pasien yang sulit dilakukan dalam pendekatan dari posterior karena nyeri atau pasien tidak kooperatif. ${ }^{1,2,5,14,15}$ Pada tahun 1963, penanda anatomis blokade saraf iskiadikus dengan pendekatan anterior berdasarkan identifikasi trokanter mayor dideskripsikan oleh Beck. 1,2,14

Pada tahun 1999, Chelly dan Delaunay ${ }^{5}$ telah mempublikasikan blokade saraf iskiadikus memakai pendekatan anterior dengan posisi terlentang, posisi ekstremitas bagian bawah dalam keadaan netral. Target titik penusukan Chelly dan Delaunay, yaitu garis tegak lurus memotong garis tengah yang menghubungkan antara batas bawah spina iliaka anterosuperior dan sudut superior simfisis pubis sejauh 8 sentimeter ke arah kaudal.

Pendekatanlainyangdiperkenalkan oleh Raj dkk. ${ }^{16}$ Pada tahun 1975 adalah posisi litotomi menggunakan marker titik pertengahan garis yang meghubungkan trokanter mayor dengan tuberositas iskiadikum dengan posisi tungkai fleksi ke arah anterior.

Barbero dkk. ${ }^{17}$ mempublikasikan penanda anatomis blokade saraf iskiadikus anterior yang dihubungkan dengan faktor tinggi badan pasien. Melalui titik pertengahan garis inguinal (antara batas bawah spina iliaka anterior superior dan batas atas pada simfisis pubis) ditarik garis tegak lurus ke arah kaudal, yaitu titik penusukan " $S$ ". Jarak titik " $S$ " dari garis inguinal dihitung mempergunakan persamaan "S" = (tinggi badan pasien dalam sentimeter 100)/10. Dari seluruh 53 subjek penelitian, angka keberhasilan blokade saraf iskiadikus dengan pendekatan ini mencapai $92 \%$.

Ukuran tulang panjang memiliki hubungan yang signifikan untuk memperkirakan tinggi badan manusia. Tinggi badan manusia dapat diperkirakan berdasarkan beberapa formula yang dikaitkan dengan faktor tulang panjang, di antaranya panjang femur. ${ }^{18}$

Gambaran anatomi saraf perifer dapat diketahui dengan pemeriksaan ultrasonografi sehingga dapat digunakan untuk membantu visualisasi blokade saraf perifer. Karakteristik saraf perifer berupa gambaran seperti sarang tawon yang terbentuk oleh jaringan ikat serta serabut saraf..$^{19}$ Chan dkk. ${ }^{20}$ mempublikasikan lokalisasi saraf iskiadikus mempergunakan ultrasonografi. Saraf iskiadikus diidentifikasi pada potongan arah transversal yang terlihat sebagai hiperekoik tunggal. Ultrasonografi memakai curve probe $2-5 \mathrm{MHz}$ memberikan gambaran saraf iskiadikus dengan kualitas yang baik. Penggunaan ultrasonografi untuk mencari lokasi saraf iskiadikus akan sangat potensial bila digunakan secara klinis untuk blokade saraf iskiadikus.

\section{Subjek dan Metode}

Penelitian ini memakai metode observasional eksperimental, pengambilan data dilakukan secara cross sectional untuk analisis korelasi dua variabel. Analisis data mempergunakan analisis korelasi linier menurut Spearman bila data tersebut tidak berdistribusi normal. Korelasi akan bermakna bila besar koefisien korelasi $(r)>0,4$ dan nilai $p<0,05$. Persamaan 
korelasi ukuran panjang femur dan ukuran tinggi badan menggunakan penanda anatomis blokade saraf iskiadikus pendekatan anterior dihitung berdasarkan analisis regresi linear dan uji analysis of variance (ANOVA) untuk menentukan kelayakan persamaan regresi linear. Uji distribusi yang digunakan menurut Kolmogorov-Smirnov. Analisis data dilakukan mempergunakan program statistical product and service solution (SPSS) v.19 dengan taraf kepercayaan 95\%.

Subjek penelitian ini yaitu peserta Program Pendidikan Dokter Spesialis Anestesiologi Fakultas Kedokteran Universitas Padjadjaran yang telah bersedia ikut penelitian ini secara sukarela pada September-November 2012. Kriteria inklusi yaitu jenis kelamin laki-laki dan berusia di atas 18 tahun. Kriteria eksklusi yaitu terdapat kelainan anggota gerak bagian bawah, memiliki riwayat patah tulang anggota gerak bagian bawah, dan menderita kelainan pertumbuhan.

Pada subjek dijelaskan mengenai penelitian dan menandatangani persetujuan (informed consent), lalu dilakukan penimbangan serta pencatatan berat badan. Pengukuran tinggi badan dan panjang femur dilakukan dalam posisi tidur terlentang. Titik LB serta titik PS ditentukan memakai panduan ultrasonografi. Penanda anatomis blokade saraf iskiadikus pendekatan anterior dilakukan dengan cara menarik garis antara batas bawah spina iliaka anterior superior (LB) dan batas atas simfisis pubis (PS) (garis inguinal).

Pengukuran/pencatatan jarak titik LB-PS dilakukan dalam satuan sentimeter. Garis tegak lurus ditarik sampai memotong pertengahan garis inguinal ke arah kaudal. Penentuan titik $P$ ini dilakukan dengan penusukan titik saraf iskiadikus melalui pendekatan arah anterior dalam posisi tubuh terlentang menggunakan ultrasonografi (USG SonoSite M-Turbo ${ }^{\circledR}$, curve probe $2-5 \mathrm{MHz}$ ), saraf iskiadikus akan mulai terlihat di bawah asetabulum femur yang diukur dalam satuan sentimeter. Pengukuran jarak titik $\mathrm{P}$ dengan garis inguinal dilakukan memakai penggaris dalam satuan sentimeter. Analisis statistik dilakukan untuk mengetahui hubungan penanda anatomis saraf iskiadikus pendekatan anterior dengan panjang femur dan tinggi badan.

\section{Hasil}

Penelitian dilakukan terhadap 92 orang subjek laki-laki mulai September sampai dengan November 2012. Parameter yang dicatat pada penelitian ini yaitu usia, panjang femur, tinggi badan, berat badan, indeks massa tubuh, jarak titik LB dengan titik PS dan titik "P" (Tabel).

Berdasarkan hasil analisis data pengukuran penanda anatomis blokade saraf iskiadikus pada pendekatan anterior dan panjang femur dari 92 subjek dengan menggunakan analisis korelasi linier menurut Spearman, diperoleh korelasi yang kuat antara penanda anatomis blokade saraf iskiadikus pendekatan anterior dan panjang femur. Koefisien korelasi (r) sebesar 0,784 dengan korelasi yang searah. Terdapat korelasi sangat bermakna antara

Tabel Karakteristik Subjek Penelitian

\begin{tabular}{lccc}
\hline \multicolumn{1}{c}{ Parameter } & Rata-rata & Rentang & Simpang Baku \\
\hline Usia (tahun) & 31,65 & $25-47$ & 4,25 \\
Panjang femur (cm) & 39,89 & $35-46,5$ & 3,46 \\
Tinggi badan $(\mathrm{cm})$ & 169,63 & $155-183$ & 5,98 \\
Berat badan $(\mathrm{kg})$ & 70,36 & $48-90$ & 10,58 \\
Indeks massa tubuh $\left(\mathrm{kg} / \mathrm{m}^{2}\right)$ & 24,41 & $17,51-31,51$ & 3,23 \\
Jarak LB-PS (cm) & 13,72 & $11,5-16$ & 0,93 \\
Titik p (cm) & 6,22 & $4-8,5$ & 1,19 \\
\hline
\end{tabular}


penanda anatomis saraf iskiadikus pendekatan anterior dan panjang femur $(\mathrm{p}=0,000)$.

Hubungan penanda anatomis pada blokade saraf iskiadikus melalui pendekatan anterior dengan panjang femur dihitung berdasarkan analisis regresi linear antara dua variabel. Dari analisis diperoleh konstanta atau intercept sebesar -4,764 dengan koefisien variabel atau slope $\left(\mathrm{a}_{1}\right)$ sebesar 0,275 , sehingga persamaan yang dihasilkan yaitu:

$$
\begin{aligned}
\mathbf{y}=\mathbf{k}_{\mathbf{1}}+\mathbf{a}_{\mathbf{1}} \cdot \mathbf{x}_{\mathbf{1}}=(\mathbf{0 , 2 7 5} \cdot \mathbf{x})-\mathbf{4 , 7 6 4} \\
\text { Keterangan: } \quad \mathrm{y}=\text { Titik “P" } \\
\mathbf{k}_{1}=\text { konstanta } 1 \\
\mathrm{a}_{1}=\text { koefisien variabel } 1 \\
\mathrm{x}_{1}=\text { panjang femur }
\end{aligned}
$$

Berdasarkan analysis of variance (ANOVA) diperoleh nilai $\mathrm{p}=0,000$ sehingga persamaan di atas layak dipergunakan. Berdasarkan hasil analisis data pengukuran penanda anatomis blokade saraf iskiadikus pendekatan anterior dan tinggi badan pada 92 subjek menggunakan analisis korelasi linier menurut Spearman diperoleh korelasi sangat kuat antara penanda anatomis blokade saraf iskiadikus pendekatan anterior dan tinggi badan. Koefisien korelasi (r) sebesar 0,921 dengan korelasi searah.

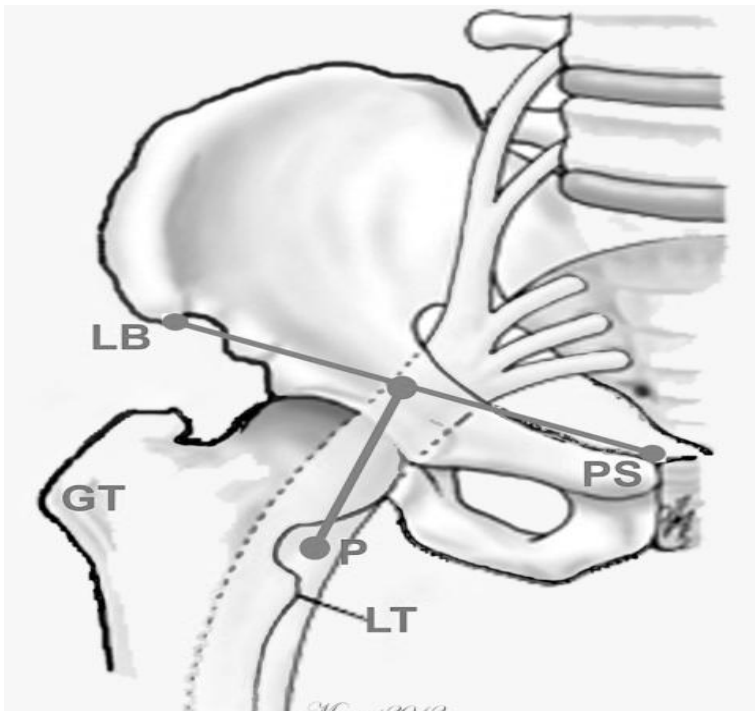

Gambar 1 Penanda Anatomis Blokade Saraf Iskiadikus Pendekatan Anterior Menggunakan Ultrasonografi (Titik "P")
Terdapat korelasi bermakna antara penanda anatomis blokade saraf iskiadikus pendekatan anterior dan tinggi badan ( $\mathrm{p}=0,000)$.

Hubungan penanda anatomis pada blokade saraf iskiadikus pendekatan anterior dengan tinggi badan dihitung berdasarkan analisis regresi linear antara dua variabel, diperoleh konstanta atau intercept-24,647 dan koefisien variabel atau slope $\left(\mathrm{a}_{1}\right) 0,182$. Persamaan yang dihasilkan yaitu:

$$
y=k_{2}+a_{2} \cdot x_{2}=(0,182 \cdot x)-24,647
$$

Keterangan: $\quad \mathrm{y}=$ Titik " $\mathrm{P}$ "

$\mathbf{k}_{2}=$ konstanta 2

$\mathrm{a}_{2}=$ koefisien variabel 2

$\mathrm{x}_{2}=$ tinggi badan

Berdasarkan uji ANOVA, diperoleh $\mathrm{p}=0,000$ sehingga persamaan di atas layak digunakan. Pada penelitian ini didapatkan hasil korelasi antara panjang garis yang menghubungkan batas bawah spina iliaka anterior superior (LB) batas atas simfisis pubis (PS) dengan titik "P".

Berdasarkan hasil analisis data pengukuran penanda anatomis blokade saraf iskiadikus pendekatan anterior dan tinggi badan pada 92 subjek laki-laki menggunakan analisis korelasi

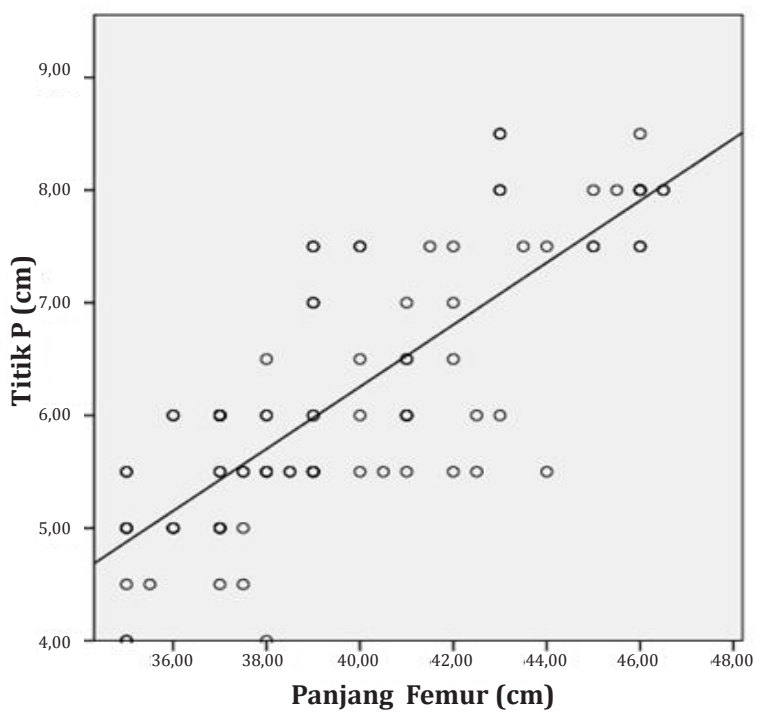

Gambar 2 Kurva Regresi Linear Hubungan Panjang Femur dengan Titik "P” 


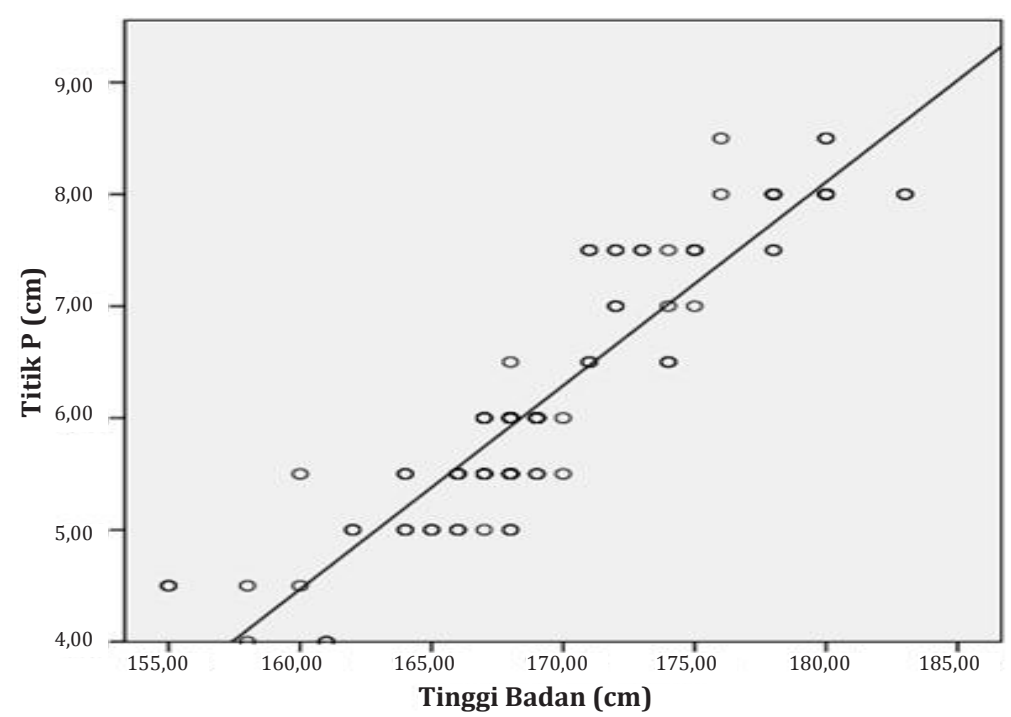

Gambar 3 Kurva Regresi Linear Hubung Tinggi Badan dengan Titik "P”

linear Spearman diperoleh kekuatan korelasi yang kuat antara penanda anatomis blokade saraf iskiadikus pendekatan anterior terhadap panjang garis yang menghubungkan bagian bawah dari spina iliaka anterior superior (LB) dengan batas atas daerah simfisis pubis (PS).

Nilai koefisien korelasi (r) adalah 0,675 dengan korelasi yang searah. Terdapat korelasi yang juga bermakna antara penanda anatomis blokade saraf iskiadikus pendekatan anterior dan panjang garis yang menghubungkan batas bawah dari spina iliaka anterior superior (LB) dengan batas atas dari simfisis pubis (PS) ( $p$ 0,000 ).

Nilai hubungan antara penanda anatomis blokade saraf iskiadikus pendekatan anterior dan panjang garis yang menghubungkan batas bawah dari spina iliaka anterior superior (LB) dengan batas atas simfisis pubis (PS) dihitung berdasarkan analisis regresi linear antara dua variabel. Analisis regresi linear menghasilkan konstanta atau intercept sebesar -6,192 dan

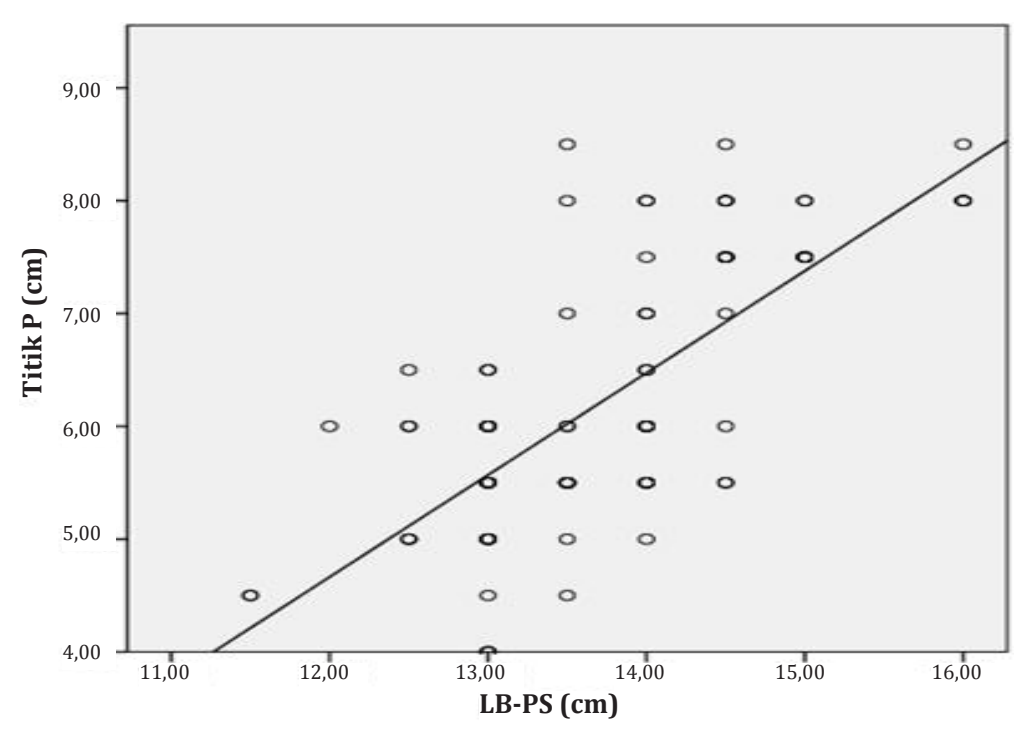

Gambar 4 Kurva Regresi Linear Hubungan LB-PS dengan Titik "P” 
nilai koefisien variabel atau slope $\left(\mathrm{a}_{1}\right)$ sebesar 0,905 , sehingga dihasilkan persamaan:

$$
y=k_{3}+a_{3} \cdot x_{3}=\left(0,905 \cdot x_{3}\right)-6,192
$$

Keterangan: $\quad \mathrm{y}=$ Titik "P"

$\mathrm{k}_{3}=$ konstanta 3

$\mathrm{a}_{3}=$ koefisien variabel 3

$\mathrm{x}_{3}=$ jarak LB-PS

Berdasarkan uji ANOVAdidapatkan $\mathrm{p}<0,001$ sehingga persamaan di atas layak digunakan. Uji normalitas distribusi terhadap data yang dipergunakan adalah Uji Kolmogorov-Smirnov yang dilakukan pada variabel numerik dengan jumlah subjek penelitian 92 orang.

Berdasarkan uji distribusi mempergunakan statistical product and service solution (SPSS) 19.0 diperoleh $\mathrm{p}=0,000$; maka distribusi data secara analitis untuk tinggi badan, panjang femur, LB-PS, dan titik penusukan $P$ tidak normal. Analisis korelasi dihitung berdasarkan analisis korelasi linear menurut Spearman.

\section{Pembahasan}

Subjek penelitian ini memiliki panjang femur rata-rata 39,89 sentimeter, tinggi badan ratarata 169,63 sentimeter, serta titik $P$ rata-rata $6,22( \pm 1.19)$ sentimeter.

Titik P ditentukan memakai ultrasonografi SonoSite M-Turbo ${ }^{\circledR}$ dengan curve probe $2-5 \mathrm{MHz}$ yang memberikan gambaran saraf iskiadikus dengan kualitas yang baik tanpa efek samping pada subjek. Saraf iskiadikus diidentifikasi dengan potongan trasversal dari femur bagian anterior sebagai struktur hiperekoik tunggal yang berjalan di bawah otot aduktor magnus.

Dari analisis data didapatkan hasil korelasi yang kuat antara penanda anatomis blokade saraf iskiadikus pendekatan anterior dan ukuran panjang femur serta koefisien korelasi (r) sebesar 0,784 dengan korelasi yang searah. Terdapat korelasi yang bermakna penanda anatomis blokade saraf iskiadikus pendekatan anterior dengan panjang femur $(p=0,000)$ dengan persamaan: Titik " $\mathrm{P} "=(0,275 \mathrm{xpanjang}$ femur)-4,764 cm. Berdasarkan persamaan tersebut, semakin panjang ukuran femur, maka titik penusukan saraf iskiadikus akan semakin jauh dari garis inguinalis. Belum ada penelitian sebelumnya yang menghubungkan panjang femur dengan titik penusukan blokade saraf iskiadikus pendekatan anterior.

Penelitian sebelumnya adalah penelitian antropometri yang menghubungkan ukuran panjang femur dengan tinggi badan manusia. Penentuan tinggi badan dapat diperkirakan dengan formula yang dihubungkan dengan tulang panjang, di antaranya dengan panjang femur. Formula yang telah banyak digunakan dalam bidang forensik antara lain formula yang dibuat oleh Topmaid dan Rollet dengan memperkirakan ukuran panjang femur kirakira 22\% tinggi badan. Formula Karl Pearson menyatakan tinggi badan $=81,306+1,88 \mathrm{x}$ panjang femur dalam $\mathrm{cm}$.

Formula Trotter-Glesser menyatakan tinggi badan=2,15 x panjang femur+72,6 $\pm 3,9 \mathrm{~cm}$. Formula Amri Amir pada tahun 1989 dibuat berdasarkan pemeriksaan pada orang hidup menyatakan ukuran tinggi badan $=1,42 \mathrm{x}$ panjang femur $+109,28 \mathrm{~cm}$.

Hubungan antara panjang femur dan titik "P" dapat dilihat pada kurva regresi linear (Gambar 1). Berdasarkan kurva regresi linear tersebut, sebaran titik "P" berada di sekitar garis regresi linear, dan terdapat dua subjek yang jaraknya paling jauh dari garis regresi linear, yaitu subjek dengan panjang femur 44 cm memiliki titik "P" 5,5 cm, sedangkan subjek yang memiliki ukuran panjang femur $43 \mathrm{~cm}$ memiliki titik "P" lebih panjang, yaitu 8,5 cm.

Hasil tersebut menunjukkan masih terdapat kemungkinan kesalahan apabila persamaan korelasi panjang femur dengan titik "P" dipakai untuk menentukan lokasi penusukan blokade saraf iskiadikus pada pendekatan anterior. Berdasarkan uji ANOVA yang dilakukan untuk menguji persamaan tersebut, didapatkan nilai $p=0,000$ sehingga persamaan tersebut layak untuk digunakan.

Berdasarkan analisis data pada penelitian ini, terdapat korelasi yang sangat kuat antara penanda anatomis blokade saraf iskiadikus pendekatan anterior dan tinggi badan. Nilai koefisien korelasi (r) sebesar 0,921 dengan korelasi yang searah. Terdapat nilai korelasi yang bermakna antara penanda anatomis 
blokade saraf iskiadikus melalui pendekatan secara anterior dan tinggi badan $(p=0,000)$ dan persamaan: Titik " $\mathrm{P}$ " $=(0,182 \mathrm{x}$ tinggi badan) $-24,647 \mathrm{~cm}$. Hal ini berbeda dengan penelitian Chelly dan Delaunay yang telah sukses mengidentifikasi saraf iskiadikus pada 22 subjek penelitian; titik "P" merupakan jarak yang konstan, yaitu $8 \mathrm{~cm}$ tegak lurus dari pertengahan garis inguinalis.

Pada penelitian yang dilakukan oleh Chelly dan Delaunay didapatkan tinggi badan ratarata 172,5 (160-185) cm, sedangkan pada penelitian ini tinggi badan rata-rata lebih rendah yaitu 169,63 cm, sehingga jarak titik penusukan blokade saraf iskiadikus rata-rata $6,22( \pm 1.19) \mathrm{cm}$ tegak lurus dari pertengahan garis inguinalis.

Dengan pendekatan yang dilakukan oleh Chelly dan Delaunay, titik penusukan yang didapatkan sama dengan titik penusukan Beck tanpa perlu mengidentifikasi trokanter mayor pasien. Sebagian pasien memerlukan 2 (dua) kali penusukan saat melakukan identifikasi saraf iskiadikus. Pada penusukan pertama, ujung jarum akan terbentur oleh komponen tulang femur, hal ini kemungkinan disebabkan karena jarum tersebut terbentur trokanter minor tulang femur. Walaupun penusukan pertama disebut penusukan yang gagal, tetapi kedalaman penusukan pertama berguna untuk memperkirakan kedalaman saraf iskiadikus saat dilakukan penusukan kedua.

Lokasi penusukan yang dilakukan oleh Chelly serta Delaunay berbeda dibandingkan dengan penelitian ini, target lokasi penusukan diperkirakan berada lebih di atas trokanter minor tulang femur, sehingga ujung jarum tidak terbentur trokanter minor tulang femur. Semakin tinggi seseorang, maka semakin jauh titik penusukan saraf iskiadikus dari garis inguinalis. ${ }^{17}$

Dari 53 subjek penelitian yang mempunyai ukuran tinggi badan rata-rata $171 \mathrm{~cm}$, ternyata angka keberhasilan blokade saraf iskiadikus yang mempergunakan stimulasi saraf dengan pendekatan Barbero dkk. sebesar 92\%.

Jarak titik rata-rata hasil penusukan pada penelitian ini lebih pendek daripada titik penusukan rata-rata yang dilakukan oleh
Barbero dkk. Perbedaan ini dapat disebabkan perbedaan demografi yang ada, kemungkinan lain juga dapat disebabkan cara pengukuran tinggi badan yang telah dilakukan. Barbero dkk. melakukan pengukuran dalam keadaan posisi berdiri tegak, sedangkan pada penelitian ini pengukuran tinggi badan tersebut dilakukan dalam keadaan posisi terlentang, sehingga dapat terjadi pemanjangan tinggi badan 1-3 $\mathrm{cm}$ akibat peregangan tulang vertebra. ${ }^{18}$

Hubungan antara data tinggi badan dan titik "P" pada penelitian ini ditampilkan pada kurva regresi linear (Gambar 2). Berdasarkan kurva regresi linear tersebut, sebaran titik "P" berada di sekitar garis regresi linear. Hal ini menunjukkan kemungkinan ada kesalahan jika kita menggunakan persamaan korelasi tinggi badan dengan titik "P" yang lebih kecil dibandingkan dengan penggunaan persamaan korelasi panjang femur dengan titik " $\mathrm{P}$ " untuk menentukan lokasi penusukan blokade saraf iskiadikus pendekatan anterior. Hal ini juga diperkuat dengan koefisien korelasi (r) antara tinggi badan dan penanda anatomis blokade saraf iskiadikus sebesar 0,921 yang melebihi koefisien korelasi (r) antara panjang femur dan penanda anatomis blokade saraf iskiadikus sebesar 0,784 .

Berdasarkan uji ANOVA didapatkan nilai $\mathrm{p}=0,000$ sehingga persamaan tersebut layak untuk digunakan.

Berdasarkan hasil sebaran titik "P" pada kurva regresi linear serta besarnya koefisien korelasi ( $\mathrm{r}$ ) menurut Spearman, maka peneliti lebih menyarankan penggunaan persamaan korelasi tinggi badan dengan titik "P" untuk menentukan titik penusukan blokade saraf iskiadikus pendekatan anterior.

Berdasarkan analisis data terdapat korelasi yang kuat antara penanda anatomis saraf iskiadikus pendekatan anterior dan panjang garis yang menghubungkan batas bawah spina iliaka anterior superior (LB) dengan batas atas pada simfisis pubis (PS). Koefisien korelasi (r) sebesar 0,675 dengan korelasi yang searah. Terdapat korelasi yang bermakna antara penanda anatomis pada blokade saraf iskiadikus pendekatan anterior dan panjang garis yang menghubungkan batas bawah dari 
spina iliaka anterior superior (LB) dengan batas atas simfisis pubis (PS) $(p=0,000)$ dan persamaan: Titik "P" $=(0,905 \times$ LB-PS $)-6,192$ $\mathrm{cm}$.

\section{Simpulan}

Terdapat korelasi yang kuat antara penanda anatomis blokade saraf iskiadikus pendekatan anterior, tinggi badan, dan juga panjang femur dengan korelasi searah.

\section{Daftar Pustaka}

1. Tsui BCH, Rosenquist RW. Peripheral nerve blockade clinical anesthesia Edisi ke-6. Philadelphia: Lippincott Williams \& Wilkins; 2009.

2. Wedel DJ, Horlocker TT. Nerve blocks. Dalam: Miller RD, penyunting. Miller's anesthesia. United States of America: Churchill Livingstone; 2009. hlm. 163974.

3. Solariki DR. Sciatic nerve blocks posterior approach. Dalam: Chelly JE, penyunting. Peripheral nerve blocks: a color atlas. Edisi ke-3. Philadelpia: Lippincott Williams \& Wilkins; 1975. hlm. 115-32.

4. Jankowski CJ, Horlocker TT, Rock MJ, Stuart MJ. Femoral 3-in-1nerve block decreases recovery room time and charges and time to hospital discharge after outpatient knee arthroscopy. Reg Anesth Pain Med. 1998;60:23S.

5. Chelly JE, Delaunay L. A new anterior approach to the sciatic nerve block. Anesthesiology. 1999;91:1655-60.

6. Hadzic A, Vloka JD, Kuroda MM, Koorn R, Birnbach DJ. The practice of peripheral nerve blocks in the United States: anational survey. Reg Anesth Pain Med. 1998;23:241-6.

7. Smith MP, Sprung J, Zura A, Mascha E, Tetzlaff JE. A survey of exposure to regional anesthesia techniques in American anesthesia residency training programs. Reg Anesth Pain Med. 1999;24:11-6.

8. Bouaziz H, Mercier FJ, Narchi P, Poupard M, Auroy Y, Benhamou D. Survey of regional anesthetic practice among French residents at time of certification. Reg Anesth Pain Med. 1997;22:218-22.

9. Ota J, Sakura S, Hara K, Saito Y. Ultrasoundguided anterior approach to sciatic nerve block: a comparison with the posterior approach. Anesth Analg. 2009;108:660-5.

10. Labat G. Its technique and clinical applications. Regional anaesthesia. Edisi ke-2. Philadelphia: Saunders Publishers; 1968.

11. Winnie AP, Ramamurthy S, Durrani Z. The inguinal paravascular technique of lumbar plexus anesthesia: The "3-in-1" block. Anesth Analg. 1973;52:989-96.

12. Ichiyanagi K. Sciatic nerve block: lateral approach with patient supine. Anesthesiology. 1959;20:601-4.

13. Dalens B, Tanguy A, Vanneuville G. Sciatic nerve blocks in children: comparison of the posterior, anterior, and lateral approaches in 180 pediatric patients. Anesth Analg. 1990;70:131-7.

14. Beck GP. Anterior approach to sciatic nerve block. Anesthesiology. 1963;24:222-4.

15. Morgan GE, Maged MS, Murray MJ. Clinical anesthesiology. Edisi ke-4. New York; McGraw-Hill Companies, Inc.; 2006.

16. Raj PP, Parks RI, Watson TD, Jenkins MT. A new single-position supine approach to sciatic-femoral nerve block. Anesth Analg. 1975;54:489-93.

17. Barbero C, Fuzier R, Samii K. Anterior approach to the sciatic nerve block: adaptation to the patient's height. Anesth Analg. 2004;98(6):1785-8.

18. Devision RJ. Penentuan tinggi badan berdasarkan panjang lengan bawah [Tesis]. Medan: Universitas Sumatera Utara; 2008.

19. Krishan K. Anthropometry in forensic medicine and forensic science-'forensic anthropometry'. Internet J Forensic Science. 2007;2(1): 5-8.

20. Chan VWS, Nova H, Abbas S, McCartney CJL, Perlas A, Quan Xu D. Ultrasound examination and localization of the sciatic nerve: a volunteer study. Anesthesiology. 2006;104(2):309-14. 